\title{
ECONOMICS SOCIALIZATION AS A NEW PARADIGM OF SOCIAL DEVELOPMENT
}

\author{
Vitalii Bocheliuk ${ }^{1}$ \\ Zaporizhzhia National Technical University, Ukraine
}

\begin{abstract}
The article analyses economics socialization of the country. The purpose of the article is to study the essence and peculiarities of economics socialization and the formation of conceptual foundations for its development. The subject of the study is theoretical and practical aspects of economics socialization in the formation of the system of economic relations in the country. In course of the study, the following methods were used: system analysis, graphical analysis, a logical generalization of results. The transformation of social and economic relations of Ukraine requires the search for new ways, their rationalization that justifies the necessity of economic socialization. In addition, modern type of society is characterized by the transition to a new level of social development, characterized by the introduction of innovations in the field of material and human capital resources. Due to this, a person is not only an important factor of economics but also an engine for development of social and economic systems of the society, which requires, in its turn, the formation of conditions for a harmonious and comprehensive development of personality as a carrier of human capital and a creator of new knowledge. In order to justify the directions of the country's socially oriented economic development as one of the important indicators of economic growth, a conceptual scheme is proposed that includes: development of human capital, formation of innovative economics, increasing the use of a country's resource potential, implementation of social policy aimed at improving life quality of the population. Based on the analysis of indicators of a country's social and economic development, the characteristics of their impact on the level of economics socialization are given.
\end{abstract}

Key words: economics socialization, development, society, country.

JEL Classification: A13, A14, F43

\section{Introduction}

Economics socialization manifests itself in the social reorientation of production, labour, and people's lives, mitigation of social differentiation and increasing the importance of social sphere. Currently, it can be affirmed that social orientation permeates all spheres of developed countries' economics and the centre of social and economic development is a human personality with his/her diverse needs.

The purpose of the article is to study the essence and peculiarities of economics socialization and the formation of conceptual foundations for its development.

The subject of the study is theoretical and practical aspects of economics socialization in the formation of the system of economic relations in the country.

The research methods are: systematic analysis - to reveal trends and schools in the economic theory in order to identify the essence of economics socialization; graphical analysis - for a schematic representation of practical aspects of the study; logical generalization of the research results - to substantiate and determine the recommendations for the formation of social development of the country's economics.

\section{Analysis of the latest research and publications}

World economic science pays much attention to the study of social aspects of economic development, as one of the natural factors of social and economic development of the country. The problem of the economics socialization in the development of society is highlighted in works of foreign scholars: M. Weber, T. Veblen, D. North, T. Parsons, E. Toffler, J. Hodgson, J. A. Schumpeter, and others. Among the domestic scholars and researchers that study the aspects of economics socialization development, one should note: O. Beliaiev, A. Bebel, A. Galchynsky, V. Geits, Y. Zaitsev, V. Lagutin, A. Kolot, H. Pylypenko, V. Tarasevych. Investigating the problems of socialization economics and its methodological principles, prominent scholars propose to derive the criteria of economics socialization 
from analysing the subject of socialization itself - people with their respective needs and interests. However, paying tribute to the results achieved, one can identify a number of underdeveloped issues of economic socialization as a strategic factor in the development of the country and society as a whole.

\section{The essence and structure of economics socialization}

Prominent American scientist R. Heilbroner under socialization means the introduction of the economic entity into various formal and informal relations through the assimilation and acceptance of universally accepted norms in society, the submission to the institutions, with the help of which a certain group of people can impose their will on other groups and classes of society. R. Heilbroner notes: "...the economics is only a hidden form of socialization or subordination” (1999, p. 33). Another famous scientist J. M. Keynes proves the need for a sufficiently broad investments socialization in order to achieve a full-time economics under the condition of compatibility of private and public interests, and he did not identify the process of socialization with the process of state regulation (1993, p. 531).

N.M. Dieieva considers the economics socialization as a process of "ensuring a good living standard, activity, and a comprehensive development of people community in general and each person in particular", proposing its implementation through the formation and maintaining the "potential of society socialization" (2005, p. 83).

In our opinion, economics socialization should be considered as a balancing act of various social groups' interests in the process of formation and implementation of economic policy, and its content should reflect qualitative changes in the structure of demand and consumption, living standards, conditions of comprehensive human development.

It should be noted that the level of economics socialization of our country is low. Among the problems of the social sphere, which impede the development of human capital, the following ones are worth mentioning:

- the social basis of population capital evolution is weak (middle class) because people that get average incomes and opportunities by their number make up the majority of this society. In the economically developed countries, the middle class with a middle level of income is the largest part of a society, and the percentage of the poor and the oligarchs are too small. It should be noticed that the level of population development in our country is much lower than in developed countries by living standard and education level. According to Credit Suisse, in order to belong to the middle class in Switzerland, it is necessary to have at least 73 thousand dollars of income per year, in the USA - 50 thousand dollars, in China and Brazil - 28 thousand dollars, in
Poland and Mexico - about 25 thousand dollars, in Russia and Thailand - 18 thousand dollars, in India 13.7 thousand dollars, and in Ukraine - 11.25 thousand dollars. (Credit Suisse - Global Wealth Report Is Released by Credit Suisse);

- currently, the quality level of social services is decreasing, namely: education, social support and security, and healthcare. Ukraine is at the lowest level among the European countries, as healthcare costs are $\$ 77$ per head. Each year, the amount of education for budget funds is being reduced. It is unlikely that much of the population will be able to study on payment basis. If in 2016 the scholarship was received by $75 \%$ of students, in 2017 it was already $45 \%$, and in 2018 it is $25 \%$. At the same time, many countries offer Ukrainians free accommodation and free study, which will also cause a massive outflow of talented young people from Ukraine.

Analysis of the main indicators of social and economic development of Ukraine in recent years suggests negative significant changes in the society (Table 1).

Analysing the main indicators of social and economic development of Ukraine for 2010-2016, one can note the negative trend - a decrease in the number of births in 2016 compared to 2010 by 101 thousand of people. In 2016, compared to 2012, the number of deaths decreased by 114.6 thousand people. Natural population growth was negative in 2016 - 186.6 thousand people, indicating an excess of deaths over births.

It is worth noting that the minimum salary and minimum subsistence rates were not always revised due to increase in the consumer price index, that is, the level of inflation was not taken into account in its calculations. According to the Law of Ukraine "On Subsistence Minimum", sets of foodstuffs must be reviewed at least once every five years, but still, in calculating the subsistence minimum, they consider methods and the minimum set of food, non-food products and services approved in 2000 (Zakon Ukrajiny "Pro prozhytkovyj minimum"). That is, if Ukrainians spent $454 \mathrm{UAH}$ for about the same minimum set of products in early 2013, now they spend 1026 UAH (Oficijnyj sajt Derzhavnoji sluzhby statystyky Ukrajiny). At the same time, the average salary was $3000 \mathrm{UAH}$, but today it is $7360 \mathrm{UAH}$.

It should be noted that at the pace of small business development, Ukraine is significantly behind the leading world countries, which stimulate and support small and medium entrepreneurship, that promotes their innovative development, improving the quality and competitiveness of manufactured products, and raising social living standards. Thus, the number of small enterprises decreased in 2016 compared with 2010 by 66087 units or by $18 \%$ (Oficijnyj sajt Derzhavnoji sluzhby statystyky Ukrajiny).

As it can be seen from the table, there is a persistent ambiguous tendency in the sphere of employment, after 2010 the unemployment rate was reduced to 2013, and in the period from 2014 to 2016, it gradually began 
Table 1

The main indicators of social and economic development of Ukraine

\begin{tabular}{|c|c|c|c|c|c|c|c|}
\hline Indexes & 2010 & 2011 & 2012 & 2013 & 2014 & 2015 & 2016 \\
\hline Living wage per person per month, UAH & 843,2 & 914,1 & 1042,4 & 1113,7 & 1176 & 1227,3 & 1388,1 \\
\hline \multicolumn{8}{|c|}{$\begin{array}{l}\text { Percentage of population with per head equivalent income per month, } \\
\text { lower legal subsistence minimum, \%: }\end{array}$} \\
\hline - monetary & 15,6 & 13,7 & 14,1 & 13,4 & 14,3 & 11,1 & 10,2 \\
\hline - general & 8,8 & 7,8 & 9,1 & 8,4 & 8,6 & 6,4 & 3,8 \\
\hline Unemployment rate, $\%$ & 8,1 & 7,9 & 7,5 & 7,2 & 9,3 & 9,1 & 9,3 \\
\hline $\begin{array}{l}\text { Small enterprises per } 10000 \text { of available } \\
\text { population, units }\end{array}$ & 78 & 77 & 76 & 82 & 75 & 76 & 68 \\
\hline Number of small enterprises, units & 357241 & 354283 & 344048 & 373809 & 324598 & 327814 & 291154 \\
\hline $\begin{array}{l}\text { Number of people graduated from } \\
\text { universities, thousand people }\end{array}$ & 654,7 & 626,5 & 612,9 & 576,3 & 484,5 & 447,4 & 386,7 \\
\hline Number of births, thousand people & 497,7 & 502,6 & 520,7 & 503,7 & 465,9 & 411,8 & 397,0 \\
\hline Number of deaths, thousand people & 698,2 & 664,6 & 663,1 & 662,4 & 632,3 & 594,8 & 583,6 \\
\hline GDP per head, UAH & 24798 & 29980 & 32480 & 33965 & 36904 & 46413 & 55899 \\
\hline
\end{tabular}

* From 2014, excluding the temporarily occupied territory of the Autonomous Republic of Crimea and the city of Sevastopol and a part of the zone of the anti-terrorist operation

to grow. During the occupation of the Donbas and Crimea territories, Ukraine lost more than 3 million workspaces. One should note that in order to reduce the unemployment rate in the state, the state should find ways to implement an economic development strategy geared towards reducing poverty and unemployment.

Also, the obstacles to the social and economic development of the country are the insufficient growth of gross domestic product (GDP) and high inflation because of the lack of integrated directions for ensuring a stable growth of the national economics (Figure 1) (Oficijnyj sajt Derzhavnoji sluzhby statystyky Ukrajiny).

According to statistics, the gross domestic product per head in 2016 amounted to $55899 \mathrm{UAH}$, which exceeded this index in 2013 by $21934 \mathrm{UAH}$, or 64.5\% (Oficijnyj sajt Derzhavnoji sluzhby statystyky Ukrajiny). At first glance, it is positive, but the citizens' number of our state has decreased, in particular, because of fighting in the east of the country, which led to increase in GDP per capita. Also, the positive growth rate is due to: the export of goods, the share of agriculture and construction. The real wage index in 2016 has significantly increased compared with 2014 by $20 \%$. Consequently, an important indicator of the country's economic prosperity and development is GDP, without which it is impossible to increase incomes and ensure social standards.

It should also be noted that Ukraine has improved the indicators of population life quality and ranked 63rd place among the countries with social development

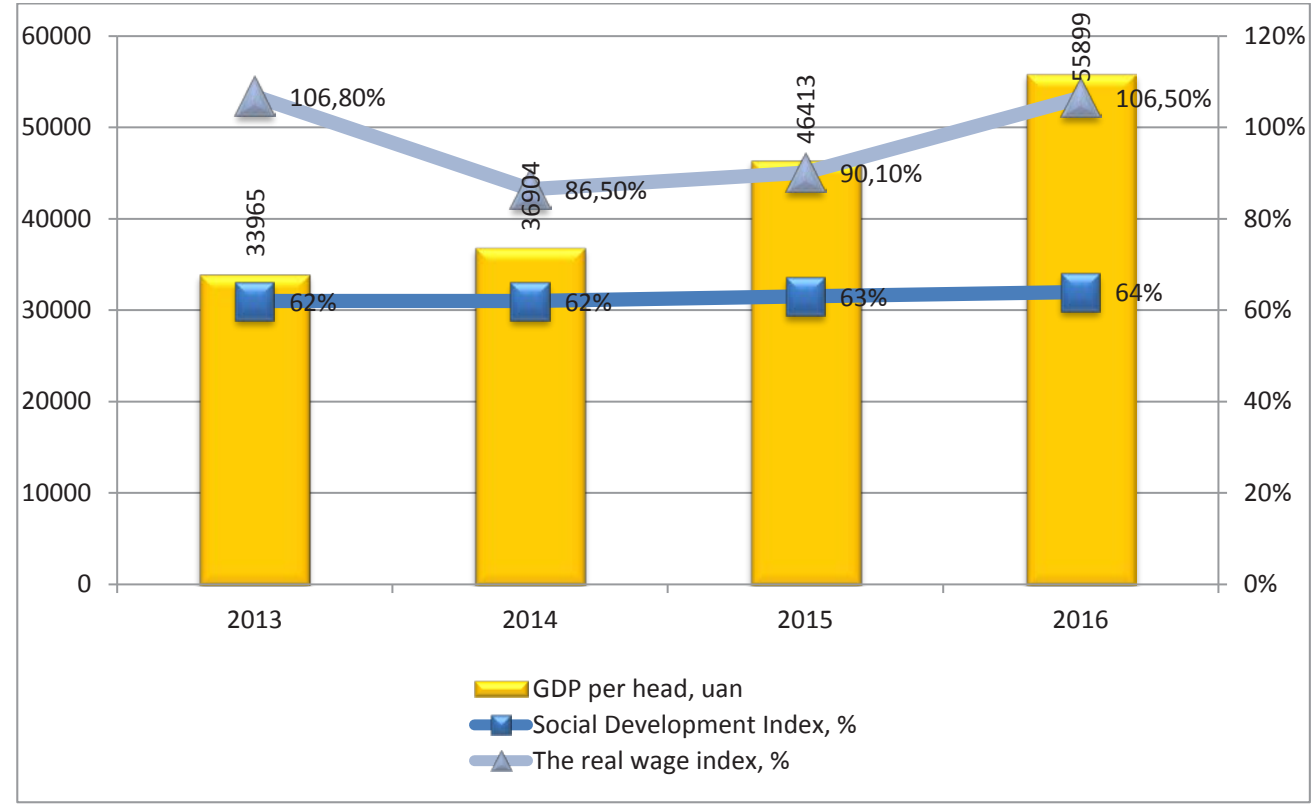

Figure 1. Indicators dynamics of social development of Ukraine 


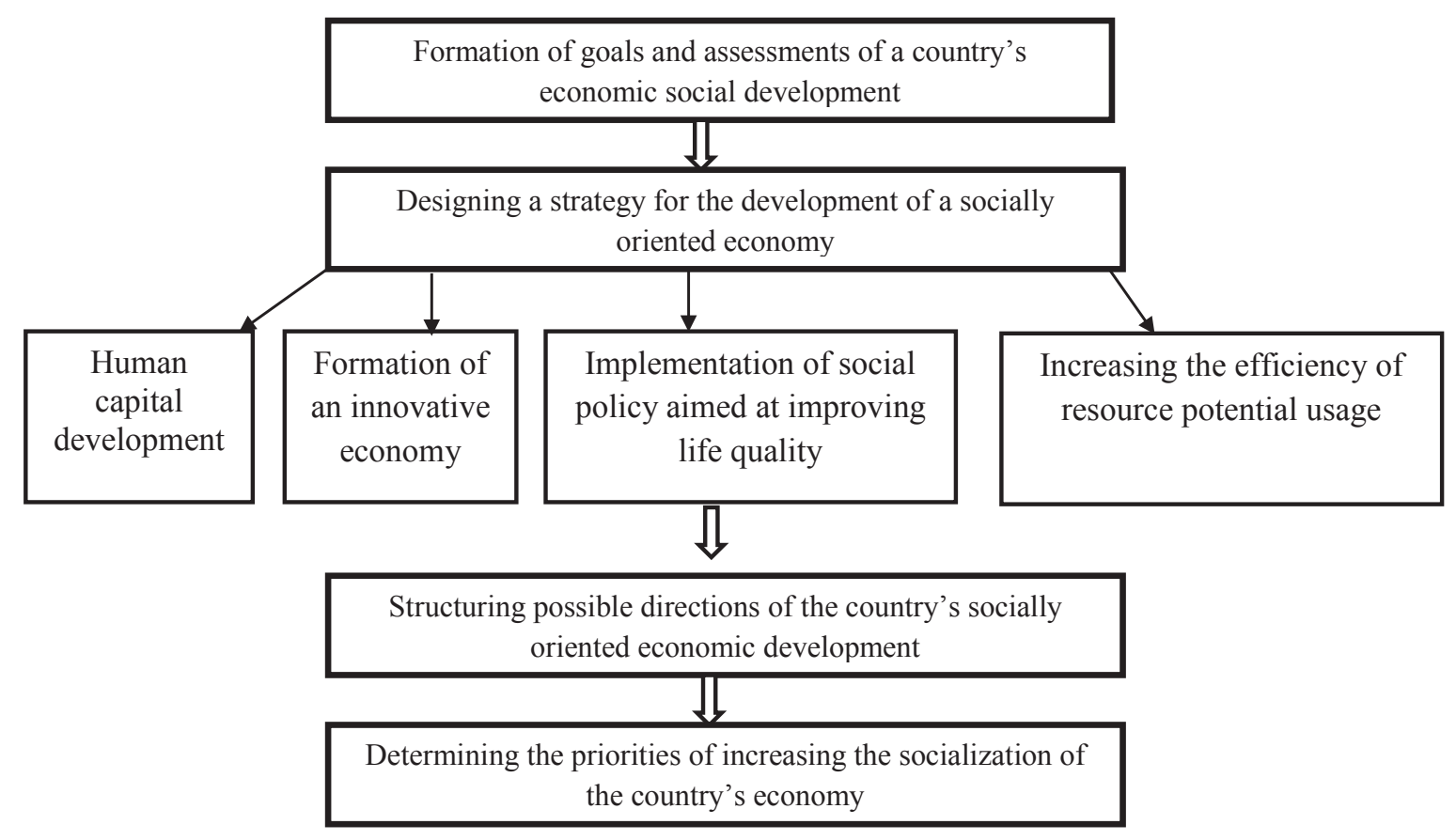

Figure 2. Conceptual scheme of developing the socially-oriented economy of the country

level below the average, as evidenced by the data of the Social Development Index (2016). A high index of higher education is observed, which is at 31 st place. Our country occupies a higher position on this indicator than countries with a similar level of GDP per head. Negative dynamics is observed in such indicators as corruption, crime rate, affordability of housing, environmental conditions, healthcare and longevity, choice freedom of life path.

Therefore, taking into account all of the above mentioned, it should be emphasized the need to form a conceptual model for the development of socially oriented economics, as one of the prerequisites for ensuring the economic and social development of the country. In addition, the definition and further implementation of strategic directions of support and development of a socially oriented economy will contribute to the achievement of Ukraine's European integration goals, increase of its investment attractiveness, and the fullest usage of the whole range of resource components of country's sustainable economic growth (Figure 2).

\section{Conclusions}

Thus, the economics socialization influences the following processes: provision of social support and protection of the population; promotion of small business as a basis for a good living standard; developing personal aspirations and motivation of population income growth, strengthening of social partnership.

In order to strengthen economics socialization, it is necessary to take a number of measures to improve the institution of social policy in the field of organization and system of remuneration, taxation of income, social protection and insurance. Solving the problems of developing a socially oriented economy is possible only on the basis of teamwork and consolidated actions of the state, representatives of large and small businesses, structured civil society.

\section{References:}

Credit Suisse - Global Wealth Report Is Released by Credit Suisse. Retrieved from: https://www.credit0suisse.com/ citizenship/en/banking/ csri/index.jsp

Djejeva N.M. (2005). Ocinka metodologho-reghuljatyvnykh pidkhodiv do socializaciji ekonomiky v konteksti rozbudovy socialjnoji derzhavy [Assessment of methodological and regulatory approaches to the socialization of the economy in the context of building a social state. Economics: the Problems of Theory and Practice: Coll. sciences.: DNY, T. 3, vol. 203, pp. 801-806.

Hodgson G.M. (2002). Darwinism in Economics: From Analogy to Ontology. Journal of Evolutionary Economics, vol. 12 , no. 3.7 .

Irtyshheva I.O., Krupica I.V. (2014). Upravlinnja instytucijnymy zminamy v umovakh socializaciji nacionaljnoji ekonomiky [Management of institutional changes in the conditions of the socialization of the national economy]. Nikolayev: NUS (in Ukrainian). 
Ivashyna O.F., Ivashyna S.Ju. (2014). Socializacija ekonomiky v konteksti postindustrialjnykh tendencij [Socialization of the economy in the context of post-industrial tendencies]. Business Inform, vol. 6, pp. 8-12.

Heilbroner R. (1999). Ekonomicheskaya teoriya kak universalniya teoriya [Economic theory as a universal theory]. Thesis, vol. 1, p. 44.

Keynes J.M. (1993). Izbrannye proizvedeniya. [Selected works]. Moscow: Economics, 543 p.

Oficijnyj sajt Derzhavnoji sluzhby statystyky Ukrajiny [Official site of the State Statistics Service of Ukraine]. Retrieved from: http://www.ukrstat.gov.ua/

Michael E. Porter, Scott Stern, Michael Green (2016). Social Progress Index. Washington. Retrieved from: http://www.socialprogressimperative.org

Zaitsev Yu.K. (2002). Sotsializatsiia ekonomiky Ukrainy ta systemna transformatsiia suspilstva: metodolohiia i praktyka [Socialization of Economy of Ukraine and systemic transformation of society: Methodology and Practice]. Kyiv: KNEU.

Zakonu Ukrajiny "Pro prozhytkovyj minimum" [The Law of Ukraine "On the Producer's Minimum"]. Retrieved from: http://zakon2.rada.gov.ua/laws/show/966-14 